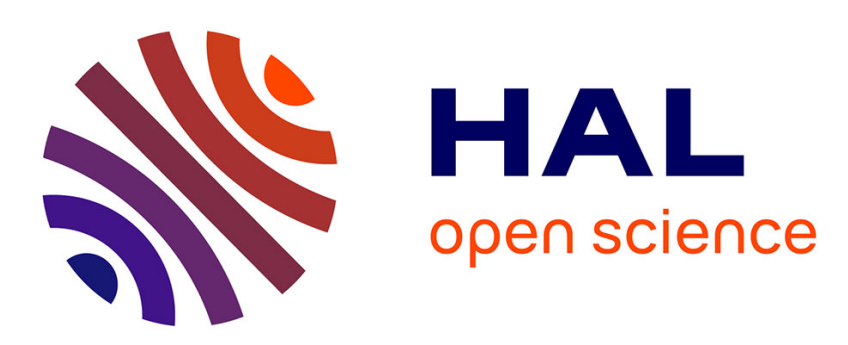

\title{
Toxicity and biochemical changes in the honey bee Apis mellifera exposed to four insecticides under laboratory conditions
}

\author{
Mohamed E. I. Badawy, Hoda M. Nasr, Entsar I. Rabea
}

\section{- To cite this version:}

Mohamed E. I. Badawy, Hoda M. Nasr, Entsar I. Rabea. Toxicity and biochemical changes in the honey bee Apis mellifera exposed to four insecticides under laboratory conditions. Apidologie, 2015, 46 (2), pp.177-193. 10.1007/s13592-014-0315-0 . hal-01284436

\section{HAL Id: hal-01284436 \\ https://hal.science/hal-01284436}

Submitted on 7 Mar 2016

HAL is a multi-disciplinary open access archive for the deposit and dissemination of scientific research documents, whether they are published or not. The documents may come from teaching and research institutions in France or abroad, or from public or private research centers.
L'archive ouverte pluridisciplinaire HAL, est destinée au dépôt et à la diffusion de documents scientifiques de niveau recherche, publiés ou non, émanant des établissements d'enseignement et de recherche français ou étrangers, des laboratoires publics ou privés. 


\title{
Toxicity and biochemical changes in the honey bee Apis mellifera exposed to four insecticides under laboratory conditions
}

\author{
Mohamed E. I. BADAwY ${ }^{1}$, Hoda M. NASR ${ }^{2}$, Entsar I. RABEA ${ }^{2}$ \\ ${ }^{1}$ Department of Pesticide Chemistry and Technology, Faculty of Agriculture, Alexandria University, 21545 El-Shatby \\ Alexandria, Egypt \\ ${ }^{2}$ Department of Plant Protection, Faculty of Agriculture, Damanhour University, 22516, Damanhour, Egypt
}

Received 15 April 2014 - Revised 23 July 2014 - Accepted 20 August 2014

\begin{abstract}
The toxicity and biochemical changes in honey bees (Apis mellifera) treated with four insecticides - acetamiprid, dinotefuran, pymetrozine, and pyridalyl — were evaluated under controlled laboratory conditions. Foraging bees were exposed to different dosages of tested insecticides by oral feeding at different dosages recommended by the manufacturers for agricultural crops in Egypt (0.01-, 0.02-, 0.04-, 0.1-, and onefold). Moreover, the acute toxicity of these insecticides was evaluated by topical application on the thorax of foragers to calculate the $\mathrm{LD}_{50}$ values. The specific activities of acetylcholinesterase (AChE), carboxylesterase, glutathione Stransferase (GST), and polyphenol oxidase (PPO) were measured in different tissues of surviving foragers after $24 \mathrm{~h}$ of treatment to explore the possible mode of action of insecticides and honey bees' strategies for detoxification and tolerance. The results indicated that regardless of how the bees were exposed to insecticides, dinotefuran was extremely toxic to adult $A$. mellifera (topical $\mathrm{LD}_{50}=0.0006 \mu \mathrm{g} /$ bee and oral feeding $\mathrm{LC}_{50}=1.29 \mathrm{mg} / \mathrm{L}$ ). Pyridalyl showed moderate toxicity compared to dinotefuran at the recommended application rate; however, acetamiprid and pymetrozine were relatively less toxic to bees $(<25 \%$ mortality at the recommended application rates). Data showed that tested insecticides varied in their influence on AChE, carboxylesterase, GST, and PPO activities that were highly correlated to their toxicity against $A$. mellifera. The biochemical analysis of carboxylesterase and GST showed that these enzymes detoxified the low doses of acetamiprid, pymetrozine, and pyridalyl, but not dinotefuran. Overall, our results are valuable not only in evaluating the toxicity of common insecticides onto honey bees, but also in highlighting the validity of enzymes activities as proper indicators for exposure to agrochemicals.
\end{abstract}

\section{Apis mellifera / insecticidal action / biochemical analysis / detoxification}

\section{INTRODUCTION}

Insecticides are applied onto a variety of agricultural crops to control a wide spectrum of pests. While pest insects are the main targets of manufactured insecticides, non-target organisms such as pollinators may come under their attack affecting about $35 \%$ of the world food crops (Velthuis and van Doorn 2006). The adverse

Corresponding author: M. Badawy,

m_eltaher@yahoo.com

Manuscript Editor: Monique Gauthier impact that broad-spectrum insecticides have on non-target beneficial insects is widely known to be a major cause of pollinator decline in cultivated areas (Blacquiere et al. 2012; Costa et al. 2014; Decourtye et al. 2004; Desneux et al. 2007; Johnson et al. 2010; VanEngelsdorp and Meixner 2010). There is no doubt that honey bees are the prominent and economically most important group of pollinators worldwide. Therefore, there is a great concern about the decline of the honey bee population (Apis mellifera) in several parts of the world mainly due to improper application of insecticides (VanEngelsdorp and Meixner 2010). Honey bees are of particular 
interest because they come to contact with various pollutants during their foraging activity, making them a perfect bioassay agent for monitoring heavy metals and pesticide toxicity in urban and rural areas (Porrini et al. 1996; Smith and Wilcox 1990). The drastic effect of pesticides in general and of insecticides in particular is not limited to the killing of non-target organisms, but is related to the abnormal behavior and function they induce. As an example of an economically important non-target organism, it is crucial to quantify the sublethal effects of various pesticides onto the behavior and function of bees as individuals and as a colony (Costa et al. 2014; Decourtye et al. 2004; Desneux et al. 2007; Mayer and Lunden 1986; Mayer et al. 2001; Porrini et al. 1996; Stone et al. 1997). While it is obviously expected that exposure to high levels of pesticides might kill foragers, sublethal exposures might also adversely affect their function (Atkins et al. 1981; Currie 1999). Therefore, while it is important to control a wide variety of agricultural pests through pesticides applications, the study of their effects on insects such as honey bees that inadvertently come into contact with them is sometimes more crucial (Desneux et al. 2007).

Among the agrochemicals known to be most toxic to bees are abamectin, chlorfenapyr, deltamethrin, and thiamethoxam, either by topical or oral administration (Rhodes and Scott 2006). Neonicotinoids are known to be the most widespread and fastest-growing class of insecticides. They are an important group of neurotoxins acting as agonists of the nicotinic acetylcholine receptors (nAChR) of insects (Elbert et al. 2008). They induce prolonged activation of the receptors as they are not hydrolyzed by acetylcholinesterase (Belzunces et al. 2012; Thany 2010). Neonicotinoids have been demonstrated to be highly toxic to A. mellifera (Iwasa et al. 2004; Laurino et al. 2011). This class includes acetamiprid, clothianidin, dinotefuran, imidacloprid, nitenpyram, thiacloprid, and thiamethoxam. The members of this group are used extensively worldwide and in Egypt for the control of major agricultural crop pests such as aphids, leafhoppers, and whiteflies. The use of this group is not limited to foliar application, but is extended for seed dressings and soil applications. In all cases, the residues of these systemic insecticides have been detected at trace levels in plant pollens and nectar. Upon viewing from a toxicity perspective, nitro-containing neonicotinoids, such as dinotefuran and thiamethoxam, were found to be more toxic than those containing a cyano-group, such as acetamiprid and thiacloprid (Laurino et al. 2011). The lower toxicity of the cyano-group neonicotinoids can be attributed to their fast biotransformation (Brunet et al. 2005) and the existence of different nAChR subtypes (Jones et al. 2006). The toxicity of insecticides such as neonicotinoids comes through the parent compounds and their byproducts. Reports showed that the majority of neonicotinoid metabolites were also shown to contribute to their toxicity, except for acetamiprid, as none of its known metabolites were yet found to be toxic (Iwasa et al. 2004).

The development of new classes or members of agrochemicals is a continuous process as insects develop resistance to the more frequently applied insecticides. Pymetrozine and pyridalyl belong to new chemical classes of insecticides and have recently become commercially available in Egypt. Both insecticides are widely used against Hemiptera pests in several agricultural crops including vegetables, potatoes, ornamentals, cotton, and citrus fruits, and against plant hoppers in rice fields. Pymetrozine is the primary member of azomethine pyridines used to control aphids, whiteflies, and plant hoppers. This is probably due to its unique mode of action that differs completely from those of classical insecticides. Pymetrozine inhibits the feeding activity of insects which subsequently die of starvation (Sechser et al. 2002). Pyridalyl, a novel insecticide, exerts excellent control against various lepidopterous and thysanopterous pests attacking cotton and vegetables. It is also effective against pests that have developed resistance to existing insecticides indicating a different mode of action from other conventional insecticide (Isayama et al. 2005).

There are several methods to measure the efficiency of pesticides, mainly against their targets which are also applicable for the non-target organisms. Enzymes are commonly used as biomarkers or indicators for the spread of environmental 
pollutants such as pesticides and heavy metals. Acetylcholinesterase (AChE), carboxylesterase, glutathione S-transferase (GST), and polyphenol oxidase (PPO) are examples of these enzymes that can be assayed to indicate any behavioral and functional changes in both target and non-target insects exposed to high or sublethal doses of insecticides. AChE depression has been widely used as a biomarker of general exposure to pollutants, especially organophosphate and carbamate pesticides ( $\mathrm{Tu}$ et al. 2009). However, the activities of other enzymes such as GSTs and carboxylesterase involved in the detoxification and removal of a wide variety of toxic compounds by conjugation or hydrolysis are also monitored (Hinton et al. 1995).

Information on the toxicity of insecticide doses used in the agricultural crops in Egypt on honey bee $A$. mellifera is very important. Therefore, the overall aim of the present research is to investigate the respective toxicity of acetamiprid, dinotefuran, pymetrozine, and pyridalyl commonly used as insecticides in Egypt onto honey bee workers (A. mellifera L.). We investigated the effects of different application doses of these insecticides on A. mellifera L. mortality by two exposure methods: topical and oral feeding at laboratory conditions. In addition, the activities of AChE, carboxylesterase, PPO, and GST enzymes as well known biochemical indicators were determined in vivo in the surviving bees after exposure to the different doses of the above-listed insecticides. This kind of information is necessary and crucial for the implementation of integrated pest management (IPM) programs which can assure the safety and maintenance of the beneficial pollinators in fields worldwide.

\section{MATERIALS AND METHODS}

\subsection{Insecticides}

The four studied insecticides were all in their formulated grades. Acetamiprid (Mospilan, $20 \% \mathrm{SP}),(E)-N$ [(6-chloro-3 -pyridinyl)methyl]- $N$ ' -cyano- $N$ methylethanimidamide was provided by Nippon Soda Co., Ltd. Japan, dinotefuran (Oshin, 20 \% SG), $N$-methyl- $N$ ' -nitro- $N$ "'-[(tetrahydro-3-furanyl)methyl]guanidine was provided by Mitsui Chemicals Agro,

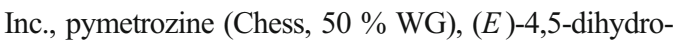
6-methyl-4-[(3-pyridinylmethylene)amino]-1,2,4triazin-3(2H)-one was provided by Syngenta Agro Switzerland, and pyridalyl (Pleo, $50 \%$ EC), 2-[3-[2,6d i c h 1 or o - 4 - [ ( 3, 3-d i c h 1 or o - 2 propeny 1)oxy]phenoxy]propoxy]-5(trifluoromethyl)pyridine was provided by Sumitomo Chemical Co., Tokyo, Japan. The chemical classes and properties of these insecticides are shown in Table I.

\subsection{Honey bee foragers}

Laboratory experiments were carried out with honey bee foragers of Apis mellifera L. (Hymenoptera: Apidae). The adult workers were obtained from ElSabahia research station, Agriculture Research Center, Ministry of Agriculture, Alexandria, Egypt, where honey bee colonies were maintained according to the standard commercial technique in the field. For this kind of risk assessment, foraging bees are considered the most ecologically relevant when they start performing external tasks (Picard-Nizou et al. 1995). Extensive literature confirms that foragers are those higher than 20 days of age in a typical colony of honey bees (Winston 1987). Based on farming records, no obvious diseases were observed on units or colonies, and no hives were treated with pesticides. This was confirmed during the collection of bees. Foraging workers were collected as explained by Iwasa et al. (2004). Briefly, four hives were exposed to smoke twice for 30-60 s before collection. Worker honey bees were collected by shaking from the top super or from the front of the hives into a clean and large plastic container. The container was covered with a solid lid, kept in good condition, and transported to the laboratory in $30 \mathrm{~min}$. The bees were kept in experimental cages $(10 \times 7 \times 12 \mathrm{~cm})$ in groups of 50 at $25 \pm 2{ }^{\circ} \mathrm{C}$ with $65 \pm 5 \% \mathrm{RH}$, a photoperiod of 12:12 (L:D), and fed a $50 \%(w / v)$ sucrose solution.

\subsection{Acute toxicity assay}

The acute toxicity of acetamiprid, dinotefuran, pymetrozine, and pyridalyl was evaluated on foraging workers of honey bees (A. mellifera L.) by two methods, oral administration through spiked syrup and topical application at controlled laboratory conditions. For the oral administration assay, five doses of each insecticide are included in which 0.01-, 0.02-, 0.04-, $0.1-$, and onefold of the manufacturer-recommended 


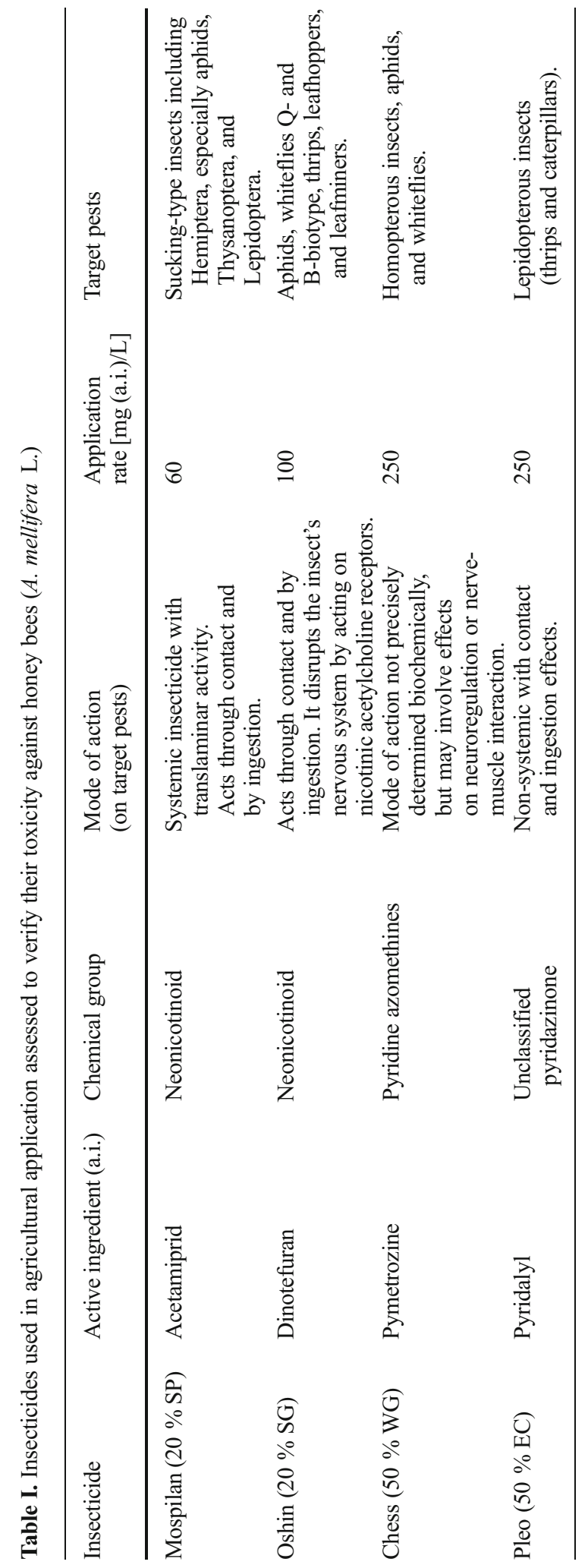


label for field rates were prepared in $50 \%(w / v)$ sucrose in triplicate. These treatments represent concentrations of $0.6,1.2,2.4,6.0$, and $60.0 \mathrm{mg}$ (a.i.)/L of acetamiprid, $1.0,2.0,4.0,10.0$, and $100.0 \mathrm{mg}$ (a.i.)/L of dinotefuran, and $2.5,5.0,10.0,25.0$, and $250.0 \mathrm{mg}$ (a.i.)/L of pymetrozine and pyridalyl. Prior to treatment with insecticides, bees were anesthetized by cooling $\left(4^{\circ} \mathrm{C}\right.$ for no longer than $3 \mathrm{~min}$ ) for handling during bioassay techniques. Each treatment of each concentration was composed of three replicates of plastic cups of 20 bees each covered with a nylon mesh with 60 honey bees total/treatment (three replicates with 20 bees/cup). The amount of insecticide solution $(20 \mathrm{~mL})$ was applied on a cotton bed and then attached to the upper surface of the nylon mesh cover of each cup (three replicates per each concentration) and bees were left to feed for $24 \mathrm{~h}$ by lapping from the fibers of the cotton wool. Bees fed with $50 \%(w / v)$ sucrose solution only were used as a control. The tests were carried out in a climate-controlled growth chamber at $25 \pm 2{ }^{\circ} \mathrm{C}, 65 \pm 5 \% \mathrm{RH}$, and photoperiod of 12:12 (L:D).

For the topical application technique, all insecticide dilutions were prepared in acetone $(\geq 99.9 \%$ SigmaAldrich, St. Louis, MO, USA). Different doses of each insecticide included 1.0 to $10 \mu \mathrm{g} /$ bee of acetamiprid and pyridalyl, 0.001 to $0.02 \mu \mathrm{g} /$ bee for dinotefuran, and 0.05 to $20 \mu \mathrm{g} /$ bee of pymetrozine tested to calculate the $\mathrm{LD}_{50}$ values. The doses were applied to the thorax of the bees using a micropipette, and all the dilutions were prepared to avoid the use of volumes higher than $5 \mu \mathrm{L}$ per bee. Control bees were treated with the same volume of acetone ( $\geq 99.9 \%$ Sigma-Aldrich, St. Louis, MO, USA). Care was taken not to spread the dose on the neck or wing hinges. Treated bees were transferred to plastic cups covered with a nylon mesh containing 20 bees/cup and fed a $50 \%(\mathrm{w} / \mathrm{v})$ sucrose solution, each cup forming a replication with three replicates used per each concentration. The treatments were kept at $25 \pm 2{ }^{\circ} \mathrm{C}, 65 \pm 5 \%$ $\mathrm{RH}$, and photoperiod of 12:12 (L:D). The bees were observed for mortality after $24 \mathrm{~h}$. Bees that did not respond to mechanical stimuli were scored as dead. The mechanical stimuli were applied by touching the body of the bees upon each evaluation, using a thin paint brush.

\subsection{Biochemical studies}

Specific activities of acetylcholinesterase (AChE), carboxylesterase, and polyphenoloxidase (PPO) were determined in the head and thorax of the surviving honey bees after $24 \mathrm{~h}$ of the oral treatment. Surviving bees were anesthetized by cooling at $4{ }^{\circ} \mathrm{C}$ for $3 \mathrm{~min}$ and the head and thorax were dissected, freed from wings, and rinsed in ice-cooled phosphate buffer ( $\mathrm{pH}$ 7.0). In addition to the three enzymes stated above, glutathione S-transferase (GST) was extracted from the midgut of tested bees. Three midguts were obtained by pulling the stings from honey bees and were then weighed.

To measure the activity of each of the aforementioned enzymes, crude extract of their assigned tissues was used. For each crude extract, the particular tissue was collected from the exposed foraging bee workers, weighed, and mixed with the proper volume of extraction mixture to make a $10 \%(\mathrm{w} / \mathrm{v})$ extract. The extraction solution consisted of $10 \mathrm{mM} \mathrm{NaCl}, 1 \%$ (w/v) Triton X-100, and $40 \mathrm{mM}$ sodium phosphate buffer ( $\mathrm{pH}$ 7.4). The tissues were homogenized in the extraction solution using a glass/ Teflon homogenizer on ice. The homogenate was filtered through cheesecloth and centrifuged at 10,000 rpm for $20 \mathrm{~min}$ at $4{ }^{\circ} \mathrm{C}$. The tissue pellet was subjected to extraction and centrifugation thrice with phosphate buffer $(\mathrm{pH}$ 7.4). The three recovered supernatant fractions containing crude enzyme were mixed and used immediately for assaying AChE, carboxylesterase, PPO, and GST activities or stored at $-20{ }^{\circ} \mathrm{C}$ until determination. All procedures were carried out at $4{ }^{\circ} \mathrm{C}$, and all of the experiments were performed in triplicate. Crude protein concentrations of different tissues were determined by the method of Lowry et al. (1951) using bovine serum albumin (BSA, SigmaAldrich, St. Louis, MO, USA) for standard curve. Activity of AChE was determined by the colorimetric method of Ellman et al. (1961) using $0.075 \mathrm{M}$ acetylthiocholine iodide (ATChI, Sigma-Aldrich, St. Louis, MO, USA) as a substrate. The assay medium $(1.5 \mathrm{~mL}$ total $)$ consisted of $1,420 \mu \mathrm{L}$ phosphate buffer $(\mathrm{pH} 8), 20 \mu \mathrm{L}$ of the crude enzyme, $50 \mu \mathrm{L}$ of $0.01 \mathrm{M}$ 5,5-dithio-bis (2-nitrobenzoic acid) (DTNB, Sigma-Aldrich, St. Louis, MO, USA), and $10 \mu \mathrm{L}$ of $0.075 \mathrm{M}$ ATChI. Over $10 \mathrm{~min}$ incubation at $37^{\circ} \mathrm{C}$, the reaction was monitored using a Unico 1200 Spectrophotometer at $412 \mathrm{~nm}$. The specific activity of $\mathrm{AChE}$ was expressed as nmoles of ATChI hydrolyzed/ $\mathrm{mg}$ protein/min. For the activity of PPO enzyme, the assay medium $(1.5 \mathrm{~mL}$ total $)$ consisted of $100 \mu \mathrm{L}$ of the crude enzyme, $700 \mu \mathrm{L}$ of $0.2 \mathrm{M}$ pyrocatechol substrate, and $700 \mu \mathrm{L}$ of $0.1 \mathrm{M}$ phosphate buffer ( $\mathrm{pH}$ 6.8) were mixed and incubated for $5 \mathrm{~min}$ at $30^{\circ} \mathrm{C}$ as described by Fattouch et al. (2010). The absorbance of developed color due to the oxidation of pyrocatechol (Sigma-Aldrich, St. Louis, MO, USA) by PPO was monitored at $420 \mathrm{~nm}$. One unit (U) of 
PPO activity was defined as the amount of enzyme that caused an increase in color absorbance by 0.001 optical density per min. The specific activity of PPO was defined as U/mg protein. Similarly, carboxylesterase activity was assayed by spectrophotometer using the substrate 4nitrophenyl acetate (4-NPA, Sigma-Aldrich, St. Louis, MO, USA) according to the method of Chanda et al. (1997). The assay medium (2 mL total) consisted of $1,925 \mu \mathrm{L}$ of $20 \mathrm{mM}$ Tris- $\mathrm{HCl}$ buffer (pH 8.0) containing $1 \mathrm{mM}$ ethylenediaminetetraacetic acid (EDTA), $50 \mu \mathrm{L}$ of enzyme extract and $25 \mu \mathrm{L}$ of $5 \mathrm{mM} 4-\mathrm{NPA}$. In this method, after $5 \mathrm{~min}$ of incubation at $25^{\circ} \mathrm{C}$, the formation of yellow 4-nitrophenol was measured at $405 \mathrm{~nm}$ and plotted against a standard curve of 4-nitrophenol. The specific activity was expressed as nmoles of the 4-NPA hydrolyzed $/ \mathrm{mg}$ protein/min. GST activity was measured as described by Saint-Denis et al. (1998) by mixing of $1,650 \mu \mathrm{L}$ of $100 \mathrm{mM}$ phosphate buffer ( $\mathrm{pH}$ 7.4) containing $1 \mathrm{mM}$ EDTA, $50 \mathrm{uL}$ of enzyme extract, $200 \mu \mathrm{L}$ of $2.5 \mathrm{mM}$ reduced L-glutathione (GSH, Sigma-Aldrich, St. Louis, MO, USA), $100 \mu \mathrm{L}$ of $1 \mathrm{mM}$ of 1-chloro-2,4-dinitrobenzene (CDNB, Sigma-Aldrich, St. Louis, MO, USA) as a substrate. The absorbance was measured at $340 \mathrm{~nm}$. One unit of activity corresponded to the quantity of enzyme conjugating $1 \mathrm{mmol}$ of GSH per min. The specific activity was expressed as $\boldsymbol{\Delta} \mathrm{OD}_{340} \mathrm{~min}^{-1} \mathrm{mg}$ protein ${ }^{-1}$. For all enzymes, blanks (reaction mixture free of crude enzyme sample) were periodically checked for nonenzymatic activities; however, no significant activity was observed for all.

\subsection{Statistical analysis}

Statistical analysis was performed using the IBM SPSS statistics version 21.0 software program (Statistical Package for Social Sciences, USA). Mortality percentages were calculated for each treatment in both bioassay methods and corrected using Abott's equation (Abbott 1925). Means and standard error (SE) were determined from three independent replicates of each treatment. The log dose-response curves were used for the determination of $\mathrm{LC}_{50}, \mathrm{LD}_{50}$, and $\mathrm{IC}_{50}$ values for the insect bioassay according to probit analysis (Finney 1971). The confidence limits of $95 \%$ were determined by least-squares regression analysis. Data of AChE, carboxylesterase, PPO, and GST activities were analyzed by one way analysis of variance (ANOVA). A difference was considered statistically significant when $P \leq 0.05$.

\section{RESULTS}

\subsection{Toxicity assay of acetamiprid, dinotefuran, pymetrozine, and pyridalyl on honey bee foragers (A. mellifera $\mathbf{L}$.)}

The results of toxicity bioassays of formulated acetamiprid, dinotefuran, pymetrozine, and pyridalyl to honey bees (A. mellifera L.) are summarized in Table 2 and Fig. 1 for the acute topical method and for the oral feeding technique, respectively. As data showed, for the topical application (Table 2), dinotefuran was obviously the most harmful to honey bees $\left(\mathrm{LD}_{50}=0.0006 \mu \mathrm{g} / \mathrm{bee}\right)$ among the four tested insecticides, while pyridalyl showed the lowest harm to the foragers $\left(\mathrm{LD}_{50}=\right.$ $6.16 \mu \mathrm{g} / \mathrm{bee}$ ), and pymetrozine and acetamiprid were relatively medium to low toxicity to bees $\left(\mathrm{LD}_{50}=0.16\right.$ and $1.69 \mu \mathrm{g} /$ bee, respectively) $24 \mathrm{~h}$ after the exposure compared to dinotefuran.

Figure 1 shows the results of the oral feeding test with sucrose syrup spiked with different examined insecticides. As shown in this figure, the honey bee $A$. mellifera $\mathrm{L}$. foragers exhibited different susceptibility to tested insecticides. Confirming the results of topical applications, dinotefuran was found to be the most toxic among the tested pesticides. At different application rates $(1.0,2.0,4.0,10.0$, and $100.0 \mathrm{mg} / \mathrm{L})$, dinotefuran killed more than $32 \%$ of bees that ingest them $\left(\mathrm{LC}_{50}\right.$ calculated as $\left.1.29 \mathrm{mg} / \mathrm{L}\right)$. Based on the performed oral feeding test, pyridalyl was shown to be relatively toxic at the recommended application rate $250 \mathrm{mg} / \mathrm{L}$ (40 \% mortality). However, acetamiprid and pymetrozine were relatively less toxic to bees (mortality does not exceed $25 \%$ ) at the recommended application rates of 60 and $250 \mathrm{mg} / \mathrm{L}$, respectively, compared to dinotefuran. The toxicity of four insecticides after $24 \mathrm{~h}$ of oral treatment followed the order of: dinotefuran > pyridalyl $>$ acetamiprid $=$ pymetrozine .

\subsection{Effects on acetylcholinesterase (AChE)}

The results shown in Table 3 revealed that the specific activity of $\mathrm{AChE}$ in the untreated bees (2.56 and 1.03 in head and thorax, respectively) was higher than that of the treated bees at all tested concentrations. All treatments significantly 
Table II. Acute toxicity of acetamiprid, dinotefuran, pymetrozine, and pyridalyl against honey bees (A. mellifera L.) by topical application.

\begin{tabular}{lllr}
\hline Compound & $\mathrm{LD}_{50}{ }^{\mathrm{a}}(\mu \mathrm{g} / \mathrm{bee})$ & Slope $\pm \mathrm{SE}^{\mathrm{b}}$ & $\left(\chi^{2}\right)^{\mathrm{d}}$ \\
\hline Acetamiprid & $1.69(0.62-2.48)$ & $2.58 \pm 0.31$ & 5.66 \\
Dinotefuran & $0.0006(0.00-0.0011)$ & $1.71 \pm 0.24$ & 6.32 \\
Pymetrozine & $0.16(0.00-0.79)$ & $0.60 \pm 0.076$ & 13.42 \\
Pyridalyl & $6.16(5.36-7.20)$ & $1.90 \pm 0.25$ & 1.97 \\
\hline
\end{tabular}

\footnotetext{
${ }^{a}$ Lethal concentration causing $50 \%$ mortality after $24 \mathrm{~h}$ with $95 \%$ confidence limits

b Slope \pm Standard Error of the concentration-mortality regression line

${ }^{c}$ Intercept \pm Standard Error of the regression line

${ }^{\mathrm{d}}$ Chi square
}

decreased AChE activity relative to the control, and the highest inhibition was observed at the highest field application rates (0.1- and onefold). A significant decrease in AChE activity was observed in honey bees exposed to acetamiprid where the specific activity decreased to 0.50 and 0.30 in head and thorax, respectively, at onefold of the field application rate $(60.0 \mathrm{mg} / \mathrm{L})$. This finding was confirmed by calculating the concentration that caused $50 \%$ enzyme inhibition $\left(\mathrm{IC}_{50}\right)$ where the $\mathrm{IC}_{50}$ values were 0.43 and $0.73 \mathrm{mg}$ (a.i.)/L for AChE of head and thorax, respectively. A significant inhibition was also found with dinotefuran
$(1.09,0.38$, and 0.00 specific activities in the head and $0.78,0.31$, and 0.00 specific activities in the thorax) and $\mathrm{IC}_{50}$ values were 0.91 and $1.45 \mathrm{mg}$ (a.i.)/L for AChE of head and thorax, respectively. The lowest effect on AChE was recorded with pymetrozine, where the specific activity ranged from 0.99 to 1.98 for the head and from 0.36 to 0.92 for the thorax. $\mathrm{IC}_{50}$ values were found to be 73.01 and $38.28 \mathrm{mg}$ (a.i.)/L for AChE of head and thorax, respectively. It can be concluded that the AChE activity was strongly inhibited by dinotefuran followed by acetamiprid, pyridalyl, and then pymetrozine in descending order.

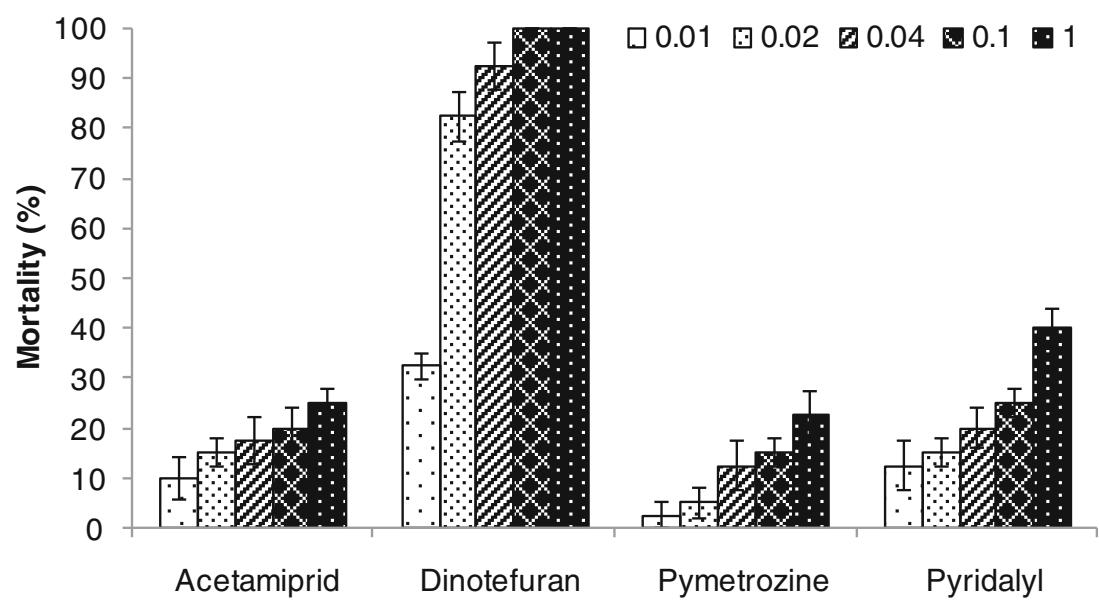

Figure 1. Acute toxicity of acetamiprid, dinotefuran, pymetrozine, and pyridalyl against honey bees (A. mellifera L.) by feeding with syrup at 0.01-, 0.02-, 0.04-, 0.1-, and onefold of the field application dose. These treatments represent the concentrations $0.6,1.2,2.4,6.0$, and $60.0 \mathrm{mg}$ (a.i.)/L of acetamiprid, 1.0, 2.0, 4.0, 10.0, and $100.0 \mathrm{mg}$ (a.i.)/L of dinotefuran, and $2.5,5.0,10.0,25.0$, and $250.0 \mathrm{mg}$ (a.i.)/L of pymetrozine and pyridalyl. Data corresponded to means $\pm \mathrm{SE}$ of three replicates 


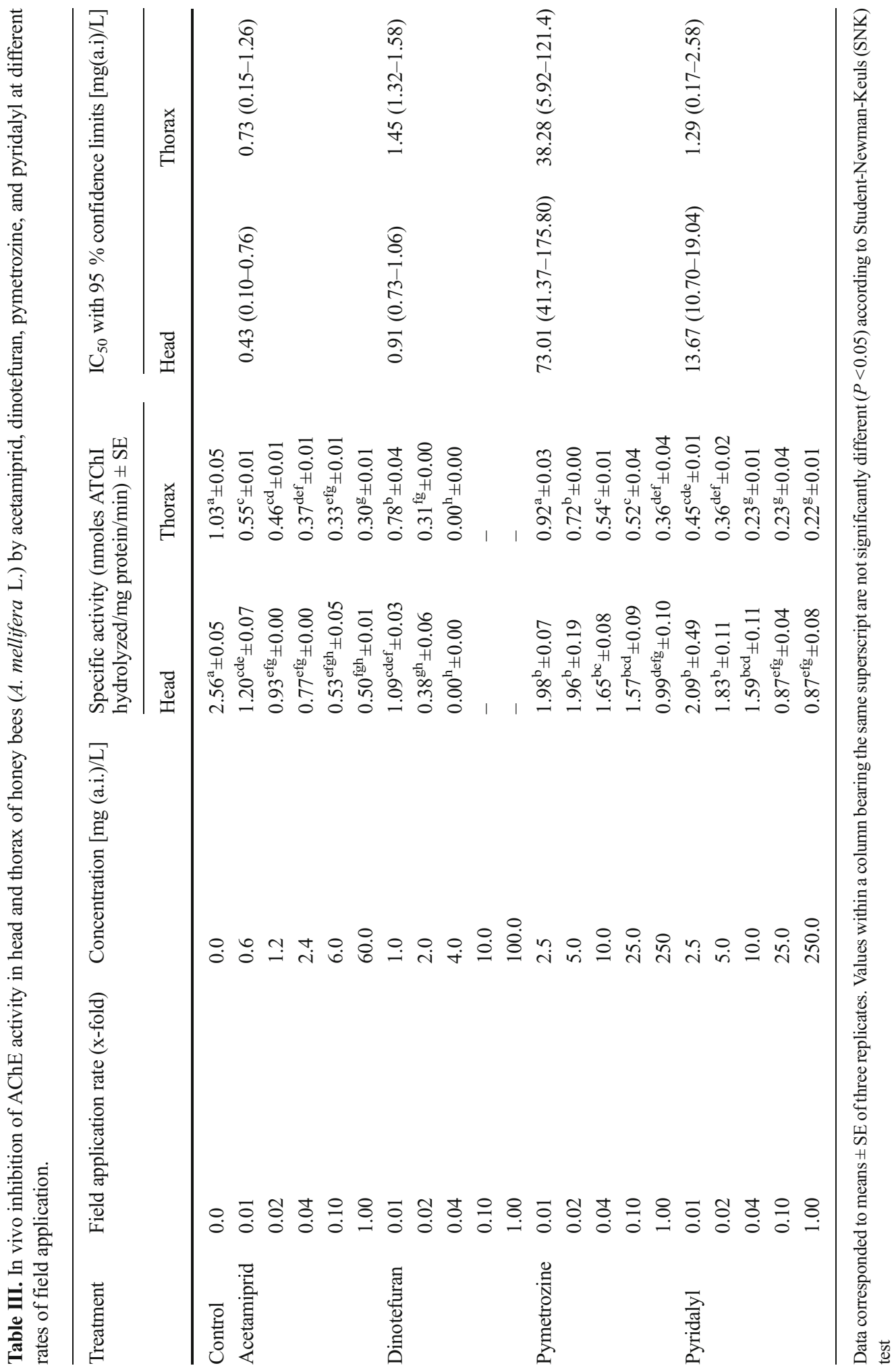



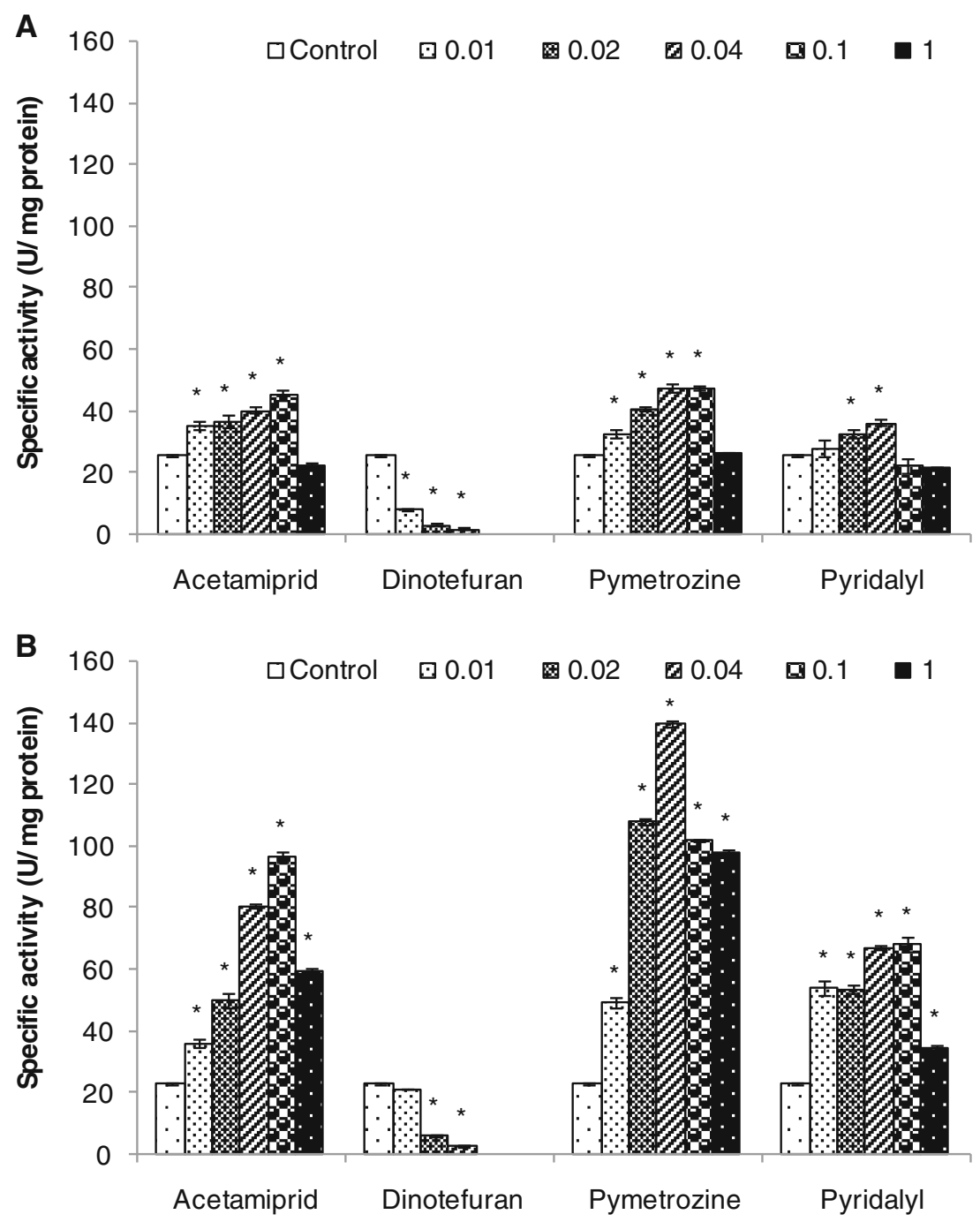

Figure 2. In vivo inhibition of polyphenoloxidase (PPO) activity in head (a) and thorax (b) of honey bees (A. mellifera $L$ ) by acetamiprid, dinotefuran, pymetrozine, and pyridalyl at different rates of field application (0.01-, 0.02-, 0.04-, 0.1-, and onefold). These treatments represent the concentrations $0.6,1.2,2.4,6.0$, and $60.0 \mathrm{mg}$ (a.i.)/L of acetamiprid, 1.0, 2.0, 4.0, 10.0, and $100.0 \mathrm{mg}$ (a.i.)/L of dinotefuran, and 2.5, 5.0, 10.0, 25.0, and $250.0 \mathrm{mg}$ (a.i.)/L of pymetrozine and pyridalyl. Data corresponded to means $\pm \mathrm{SE}$ of three replicates. Asterisks indicate a significant difference with the control $(P \leq 0.05)$.

\subsection{Effect on polyphenoloxidase (PPO)}

The data shown in Fig. 2 represents the in vivo effect of acetamiprid, dinotefuran, pymetrozine, and pyridalyl on PPO isolated from the head and thorax of surviving bees (A. mellifera L.) after $24 \mathrm{~h}$ of exposure at different rates of field application. The results showed that the treatments below the recommended field application rates (0.01-, 0.02-, 0.04-, and 0.1-fold) of acetamiprid, pymetrozine, and pyridalyl induced a significant activation or stimulation of the enzyme compared to the untreated bees. However, the enzyme was slightly inhibited by the recommended doses of field application of acetamiprid and pyridalyl particularly in bee heads. Our data showed that 

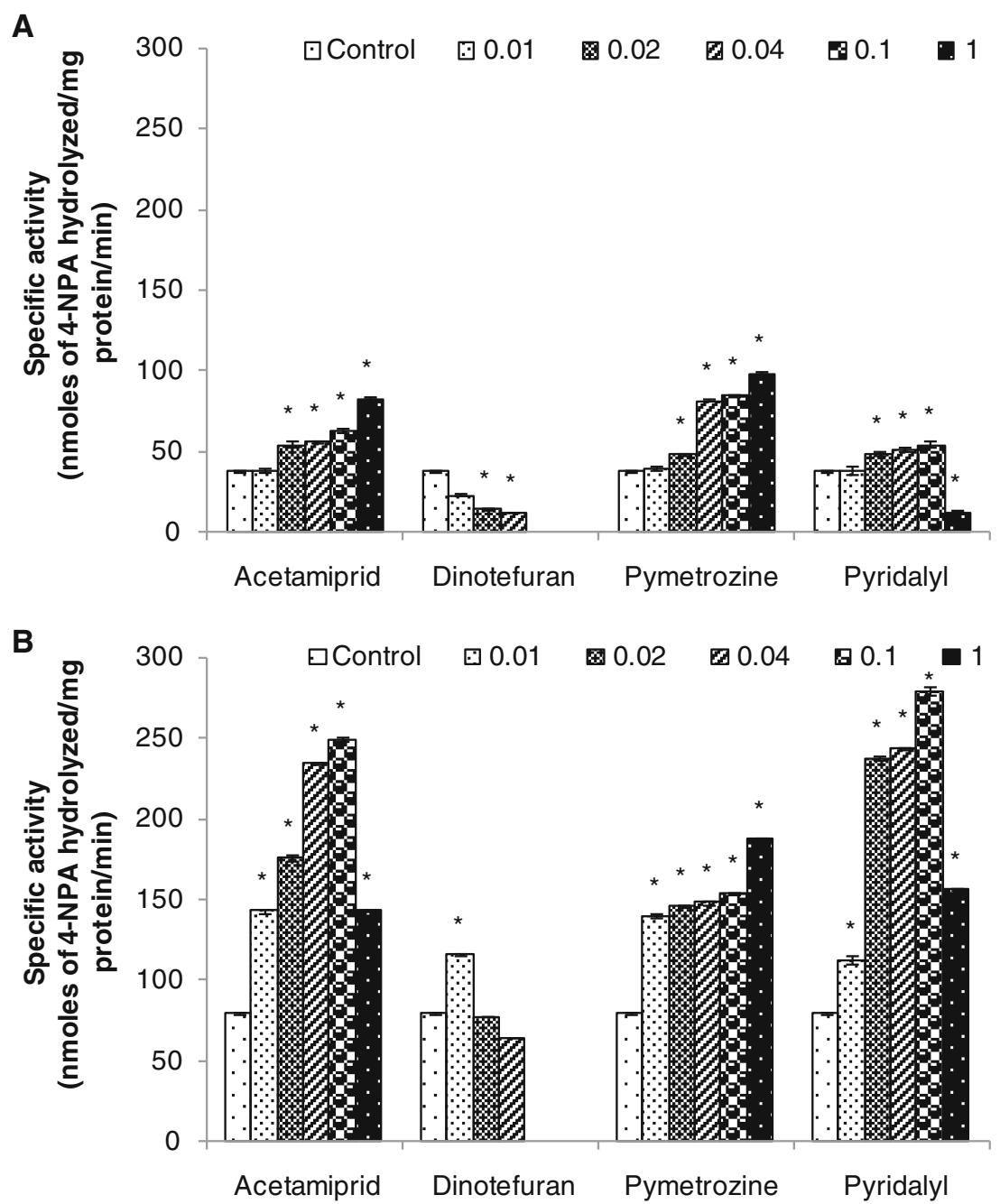

Figure 3. In vivo inhibition of carboxylesterase activity in head (a ) and thorax (b) of honey bees (A. mellifera L) by acetamiprid, dinotefuran, pymetrozine, and pyridalyl at different rates of field application (0.01-, 0.02-, 0.04-, 0.1-, and onefold). These treatments represent the concentrations $0.6,1.2,2.4,6.0$, and $60.0 \mathrm{mg}$ (a.i.)/L of acetamiprid, $1.0,2.0,4.0,10.0$, and $100.0 \mathrm{mg}$ (a.i.)/L of dinotefuran, and 2.5, 5.0, 10.0, 25.0, and $250.0 \mathrm{mg}$ (a.i.)/L of pymetrozine and pyridalyl. Data corresponded to means $\pm \mathrm{SE}$ of three replicates. Asterisks indicate a significant difference with the control $(P \leq 0.05)$

dinotefuran significantly inhibited PPO activity in both the head and thorax. No bees survived at high doses 0.10 - and onefold of the field application dose $(10.0$ and $100.0 \mathrm{mg} / \mathrm{L})$ of dinotefuran, hence no enzyme activity was determined.

\subsection{Effect on carboxylesterase}

Carboxylesterases are key detoxification enzymes of pesticides. These esterases are involved in the biochemical mechanism of resistance to pesticides in certain species of pests. The data in Fig. 3 indicate that acetamiprid, pymetrozine, and pyridalyl all induced a significant stimulation of the carboxylesterase. However, dinotefuran significantly inhibited enzyme activity at all levels of application except at 0.01 -fold of field application dose in the thorax (specific activity $=115.02$ compared to 78.77 in the untreated bees). No bees survived at high doses 0.10- and onefold of the 


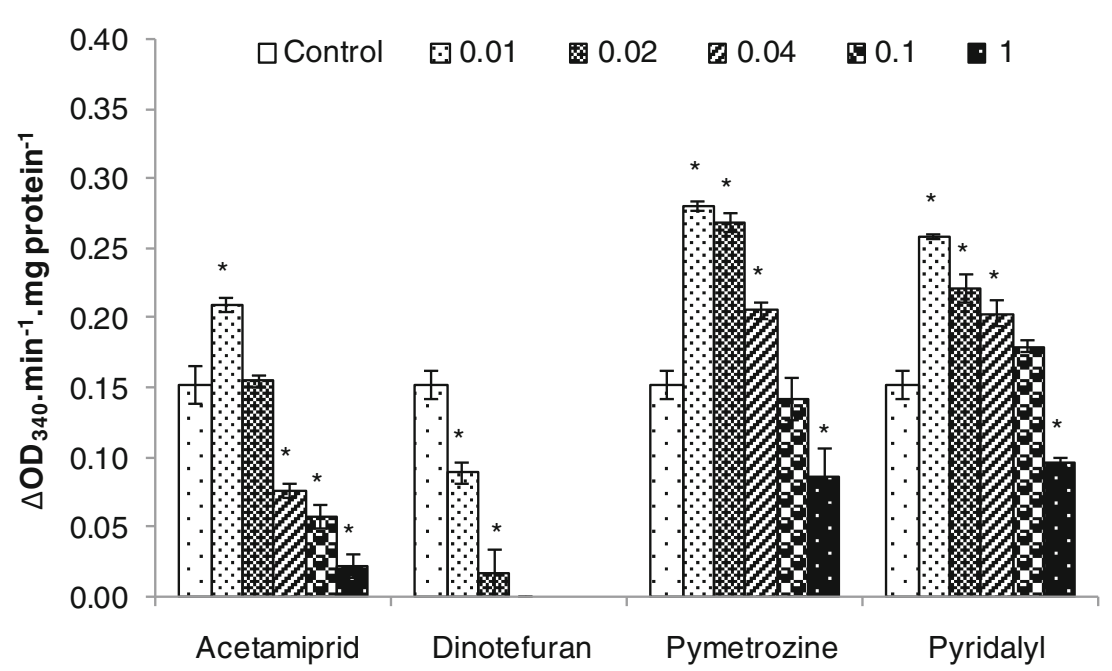

Figure 4. In vivo inhibition of glutathione S-transferase (GST) activity in midgut of honey bees (A. mellifera $L$ ) by acetamiprid, dinotefuran, pymetrozine, and pyridalyl at different rates of field application (0.01-, 0.02-, 0.04-, 0.1-, and onefold). These treatments represent the concentrations $0.6,1.2,2.4,6.0$, and $60.0 \mathrm{mg}$ (a.i.)/L of acetamiprid; $1.0,2.0,4.0,10.0$, and $100.0 \mathrm{mg}$ (a.i.)/L of dinotefuran; and 2.5, 5.0, 10.0, 25.0, and $250.0 \mathrm{mg}$ (a.i.)/L of pymetrozine and pyridalyl. Data corresponded to means \pm SE of three replicates. Asterisks indicate a significant difference with the control $(P \leq 0.05)$

application rate in the field $(10.0$ and $100.0 \mathrm{mg} / \mathrm{L})$, where no enzymatic activity was determined. All levels of application of acetamiprid and pymetrozine doses showed detoxification by carboxylesterase and the activity was significantly increased by increasing the concentration compared to untreated bees. Pyridalyl also showed an increase of enzyme activity at levels of 0.01 -, $0.02-, 0.04$-, and 0.10 -fold of the rate of application $(2.5,5.0,10.0$, and $25.0 \mathrm{mg} / \mathrm{L}$, respectively); however, in onefold of the field application dose $(250.0 \mathrm{mg} / \mathrm{L})$, the enzyme extracted from the head was significantly $(P<0.05)$ inhibited (specific activity $=11.52$ compared to 37.00 in the control).

\subsection{Effect on glutathione S-transferase (GST)}

The in vivo effect of four insecticides on the activity of GST isolated from abdomen of surviving bees (A. mellifera L.) after $24 \mathrm{~h}$ of oral treatment was studied and the results are presented in Fig. 4. As regards the activity in the untreated bees, there is a significant increase $(P<0.05)$ at low treatments with all tested insecticides, except dinotefuran, that significantly inhibited the GST at all tested concentrations (0.01-, 0.02-, and 0.04fold of the rate of application in the field). The specific activity declined from 0.15 in the untreated bees to $0.09,0.02$, and 0.00 at $0.01-, 0.02-$, and 0.04 -fold, respectively, of the field application dose of dinotefuran $(1.0,2.0$, and $4.0 \mathrm{mg} / \mathrm{L}$, respectively). No bees survived at high doses 0.10 and onefold of the field application dose (10.0 and $100.0 \mathrm{mg} / \mathrm{L}$ ), hence no enzyme activity was assessed. Acetamiprid showed an increase in enzyme activity at 0.01 - and 0.02 -fold of the field application dose ( 0.6 and $1.2 \mathrm{mg} / \mathrm{L}$, respectively), while the enzyme was significantly inhibited at 0.04-, 0.1-, and onefold of the field application dose $(2.4,6.0$, and $60.0 \mathrm{mg} / \mathrm{L}$, respectively). Most of the pymetrozine and pyridalyl treatments caused a significant increase $(P<0.05)$ in GST activity. Pymetrozine also recorded a significant increase in enzyme activity at $0.01-, 0.02-$, and 0.04 -fold of the field application dose (specific activities $=0.28,0.27$, and 0.21 , respectively); however, an inhibition was found at 0.1 - and onefold of the field application dose. Pyridalyl showed an increase of enzyme activity at concentrations of 0.01-, 0.02-, 0.04-, and 0.10-fold of the rate of application $(2.5,5.0,10.0$, and $25.0 \mathrm{mg} / \mathrm{L}$, 
respectively); however, in onefold of the field application dose $(250.0 \mathrm{mg} / \mathrm{L})$, the enzyme was significantly $(P<0.05)$ inhibited (specific activity $=0.10$ compared to 0.15 in the untreated bees).

\section{DISCUSSION}

The study of the effects of pesticides on insects requires measurement of reasonable and appropriate parameters quantitatively. There has been little work in insects examining biomarkers for sublethal exposure to pesticides. Honey bees are one of the few types of insects where pesticide-related death incidents are not intended nor welcomed. Bees may proceed as a reliable biomarker for environmental pollution through their reduced pollination capability, the presence of pesticides residues in their honey, their mortalities, and enzyme inhibition in their tissues when exposed to lethal rates of pollutants (Hyne and Maher 2003; Porrini et al. 2002). Biomarkers can be defined as observable or measurable modifications at the molecular, cellular, physiological, and behavioral levels which reveal the exposure of an organism to xenobiotics. The use of biomarkers in the environmental pollution detection enables monitoring of stress responses ranging from just the biomolecular/biochemical changes to the population and community levels (Adams et al. 1989). Nevertheless, there is less work correlating the population and community changes to changes in selected biomarkers in field-collected bees due to multiple interfering environmental factors and difficulties in estimation. Therefore, laboratory conditions are more appropriate for these correlations to be estimated accurately.

Under laboratory conditions, high levels of pesticides are proven to kill foragers, while sublethal concentrations of pesticides have adversely affected colony function (Decourtye et al. 2005; Smirle et al. 1984; Currie 1999). Insecticide actions on the mortality and biochemistry of honey bees have been the subject of many studies (Atkins et al. 1981; Costa et al. 2014; Decourtye et al. 2004; Mayer and Lunden 1986; Mayer et al. 2001; Porrini et al. 1996; Rabea et al. 2010). In the present study, the analysis of paired data resulting from control and acetamiprid, dinotefuran, pymetrozine, and pyridalyl administration for $24 \mathrm{~h}$ onto foragers allowed excellent comparisons to be made between these toxic insecticides in their formulated form. The results showed differences in the reaction of honey bees to the tested insecticides, probably due to the different modes of action of each insecticide. Moreover, the data presented a variation among the tested insecticides in mortality in oral exposures that is not simply due to differential antifeedant effects. Using two different techniques in our study, toxicity data due to oral feeding and topical application were found to be perfectly correlated. More specifically, it can be noted from our results that the nitro group in neonicotinoids such as dinotefuran causes a higher toxicity to bees than that of cyano substitution in acetamiprid. The $\mathrm{LD}_{50}$ for acetamiprid was $1.69 \mu \mathrm{g} / \mathrm{bee}$ against $0.0006 \mu \mathrm{g} / \mathrm{bee}$ for dinotefuran (Table II). Iwasa et al. (2004) has estimated the $\mathrm{LD}_{50}$ values for acetamiprid and dinotefuran (technical forms) against honey bees (A. mellifera $L$ ) as 7.1 and $0.075 \mu \mathrm{g} / \mathrm{bee}$, respectively. This variation in the toxicity values might be because of the nature of the formulations and purity of the tested insecticides. In the present study, insecticides were formulated rather than technical grade. Therefore, they showed lower $\mathrm{LD}_{50}$ values (much more toxicity) than those obtained in studies using technical grades of the tested insecticide, confirming that the formulation ingredients often increase the toxicity of the active ingredient for honey bees (Elbert et al. 2000; Iwasa et al. 2004; Suchail et al. 2000).

Acetamiprid belongs to the family of neonicotinoids, a new insecticide class with many members that are important in agriculture due to their activity against sucking insects and some Heteroptera, Coleoptera, and Lepidoptera (Yamamoto and Casida 1999). Dinotefuran is also one of the neonicotinoid insecticides (contains a nitro substitution) developed by Mitsui Chemicals for the control of insect pests such as aphids, whiteflies, thrips, leafhoppers, leafminers, and sawflies on leafy vegetables, in residential and commercial buildings, and for professional turf management. By inhibiting the nicotinic acetylcholine receptor (nAChR), neonicotinoids disrupt the insect's nervous system by prolonged activation of the receptors as they are not hydrolyzed by acetylcholinesterase, leading to death of the insects (Belzunces et al. 2012; Thany 2010). 
Besides this direct effect, neonicotinoids have sublethal effects on honey bees (Aliouane et al. 2009; Blacquiere et al. 2012; Cresswell et al. 2012; Henry et al. 2012; Laurino et al. 2011). In order to avoid harming beneficial insects such as honey bees, dinotefuran should not be applied during bloom. Iwasa et al. (2004) found that clothianidin, imidacloprid, and thiamethoxam (neonicotinoid contains a nitro substitution) showed high acute toxicity to honey bee workers with $\mathrm{LD}_{50}=0.0179,0.0218$, and $0.0299 \mu \mathrm{g} / \mathrm{bee}$, respectively. A similar high toxicity of imidacloprid and thiamethoxam was also found for the bumble bee Bombus terrestris (Mommaerts et al. 2010). The lower toxicity of the cyano-group neonicotinoids can be attributed to their fast biotransformation (Brunet et al. 2005; Suchail et al. 2004) and the existence of different nAChR subtypes (Jones et al. 2006). However, species differ in their susceptibility to insecticides, whereas bumble bees (Bombus impatiens) were found to be more tolerant to clothianidin and imidacloprid than Osmia lignaria and Megachile rotundata. Schmidt (1996) reported that imidacloprid at the field dose was highly toxic to honey bees (oral $\mathrm{LD}_{50}=0.0037 \mu \mathrm{g} / \mathrm{bee}$, topical $\left.\mathrm{LD}_{50}=0.081 \mu \mathrm{g} / \mathrm{bee}\right)$. Bees treated with imidacloprid were less active; the communicative capacity seemed to be impaired (Medrzycki et al. 2003) and this compound can induce behavioral changes such as a decrease in foraging activity (Decourtye et al. 2004). While most of the toxicity studies focused on imidacloprid due to its low toxicity and common use, in the current study, we paid attention to other insecticides.

Pymetrozine, a newer systemic insecticide of the pyridine-azomethin family, is currently presented as a potential good product for IPM programs (Sechser et al. 2002) due to its selectivity and efficiency. For example, the selectivity of pymetrozine against its targets with less mortality of some beneficial arthropods has been demonstrated (Jansen et al. 2011). Also, it was reported that pymetrozine showed high efficiency when combined with natural predators against aphids at reduced field doses (Acheampong and Stark 2004). In our results presented above, pymetrozine showed moderate toxicity to bees only when applied by topical application $\left(\mathrm{LD}_{50}=\right.$ $0.16 \mu \mathrm{g} / \mathrm{bee}$ ) with no sign of toxicity when applied by oral feeding on syrup. This result is in agreement with the result of Abramson et al. (2012) who found that exposure up to 100 times the recommended dosage of pymetrozine (Plenum WG-50 ${ }^{\circledR}$ ) is required to show its effect on proboscis extension conditioning in honey bees (A. mellifera: Hybrid var. Buckfast). Therefore, our results confirmed other study results that showed pymetrozine can be considered harmless to honey bees at the recommended dose (250 mg a.i./L).

Pyridalyl, the fourth insecticide investigated in this study, is a new active substance of unclassified pyridazinone family. Pyridalyl has received not much attention so far worldwide. It provides a unique mode of action, fighting against the resistance of thrips at all life stages and controlling lepidopterous insects. It is also effective on pests that have developed resistance to existing insecticides, indicating a different mode of action from any other conventional insecticide. Based on our data, pyridalyl showed low toxicity to honey bees, suggesting that it should be used commonly in agricultural crop protection. This finding is in agreement with that of Isayama et al. (2005) who reported that no acute toxicity of pyridalyl was observed on non-target insects including the pollinating insect Bombus terrestris. Therefore, we see pyridalyl is compliant with IPM programs, either applied via body-dipping or direct spray methods.

The toxicity of pesticides measured by mortality of target and non-target organisms is mostly the focus of many studies; behavior and biochemical changes received less attention. In our current investigation, we highlight the sublethal effects of four common insecticides. In environmental toxicology, some enzymes are particularly useful as they are the target sites of pesticides and their inhibition is positively correlated to the degree of pesticide toxicity (Badiou-Bénéteau et al. 2008). Ideally, the mode of action of pesticides would be more specific to undesirable target organisms, but unfortunately, many non-target species like honey bees are unintentionally affected (Murphy 1986). The responses of some biochemical parameters, such as alkaline phosphatase, acetylcholinesterase, and glutathione-S-transferase have been extensively characterized in laboratory studies after the exposure of honey bees to various chemicals (Badiou-Bénéteau et al. 2008, 2012). According 
to their response profiles to chemicals, honey bees can be considered promising tools for environmental biomonitoring programs. However, no in situ validations have been performed to date. In the present study, the responses of AChE, carboxylesterase, GST, and PPO were evaluated in vivo not only to correlate the mortality of honey bees $A$. mellifera to the sites of inhibition, but also to investigate the possibility to use such enzymes as biomarkers of behavioral and biochemical changes in insects. AChE is a specific target enzyme for organophosphates and carbamates poisoning (specific protein binding). Evidence has emerged that a decrease of AChE activity is not exclusively limited to organophosphates and carbamates. Other new classes of insecticides such as neonicotinoids are also involved in $\mathrm{AChE}$ reduction and act on the insect nicotinic acetylcholine receptor (Frasco et al. 2005). These pesticides or their metabolites can either entirely inhibit or just reduce $\mathrm{AChE}$ activity by unspecific protein binding (e.g., interaction with serine groups outside of the catalytic subunit). AChE is known to be largely distributed in the bee brain (Huang and Knowles 1990). This was confirmed in this study, where high levels of $\mathrm{AChE}$ were found in the heads of bees (2.56 nmoles ATChI hydrolyzed/ $\mathrm{mg}$ protein $/ \mathrm{min}$ ) compared to the thorax (1.03 nmoles). The present study revealed that all doses of four tested insecticides induced a significant decrease in AChE activity that is maximized at the highest field application rates (0.1- and onefold). Recently in another study, we tested the effect of two insect growth regulators (chlorfluazuron and oxymatrine) and a biopesticide (spinosad) on the honey bee workers (Apis mellifera L.) (Rabea et al. 2010). The results indicated that oxymatrine and spinosad with the same tested concentrations $(2.5,5,10$, and $20 \mathrm{mg} /$ L) significantly inhibited the AChE activity in different organs of the honey bee workers. Interestingly, the highest inhibition percentage due to oxymatrine and spinosad exposure was found with the AChE enzyme isolated from the thorax rather than that originating from the brain. On the contrary, chlorfluazuron caused 39.65 and $44.22 \%$ reduction at 2,000 and $4,000 \mathrm{mg} / \mathrm{L}$, respectively, in the activity of head-originating AChE (Rabea et al. 2010).
Metabolic insecticide resistance in insects is mediated by three major groups of detoxifying enzymes: the cytochrome P450 monooxygenases (P450s), the carboxylesterases, and GST. GST is a detoxifying enzyme that catalyzes the conjugation of a variety of electrophillic substrates to the thiol group of glutathion (GSH), producing less toxic forms, and it appears to contribute to cellular protection against oxidative damage (Hayes et al. 2005; Mannervik et al. 1985). Increased levels of GST have been associated with higher resistance to a wide variety of insecticides. In the present study, the increase in GST activity, reaching up to $186 \%$ of control activity at lower levels of insecticides, strongly suggests the induction of oxidative stress by acetamiprid, pymetrozine and pyridalyl. On the other hand, dinotefuran inhibited GST at all tested recommended doses. Induction of GST activity has been reported in many insects following treatment with insecticides such as dithiocarb, cypermethrin, dimethoate, and chlorpyrifos (Lagadic et al. 1993; Singh et al. 2006). Badiou-Bénéteau et al. (2012) added that thiamethoxam caused 119 and $156 \%$ increase in both GST and catalase activities, respectively. This induction may be due to the glutathionedependent enzymes system that provides major protection against the toxic agents.

Carboxylesterase plays a major role in detoxification of numerous endogenous and exogenous agrochemicals through hydrolysis. In the present study, the carboxylesterase activity was increased with different application rates of acetamiprid, pymetrozine, and pyridalyl, and was negatively affected by dinotefuran. These results suggest that metabolic detoxification via carboxylesterase contributes significantly to honey bee tolerance to acetamiprid, pymetrozine, and pyridalyl (Badiou-Bénéteau et al. 2012). Considering that the tested pesticides in the present study were in formulated forms, it is also possible that detergents or other additives in the formulations solubilized or otherwise increased levels of some enzymes such as PPO activity.

\section{CONCLUSIONS}

The present study evaluated the toxicity of acetamiprid, dinotefuran, pymetrozine, and 
pyridalyl on foraging workers of honey bees (A. mellifera L.) by two common methods of treatment. The activity of $\mathrm{AChE}$, carboxylesterase, GST, and PPO enzymes were also determined to explore the opportunity of using such enzymes as biomarkers for honey bees exposure to insecticides. The results indicated that dinotefuran was highly toxic to bees with topical $\mathrm{LD}_{50}$ value of $0.0006 \mu \mathrm{g} / \mathrm{bee}$ and oral feeding $\mathrm{LC}_{50} 1.29 \mathrm{mg} / \mathrm{L}$. It is, therefore, suggested that this insecticide must be used only with greatest care to avoid its drastic negative effects on nontarget insects essential for agricultural purposes. There were differences in the reactions of honey bees to the four insecticides, probably due to their different modes of action. Thus, our results are of great importance as they can be used as guidelines regarding which insecticides may be toxic to these insects. Results of this study suggested that acetamiprid, pymetrozine, and pyridalyl have low toxicity to the honey bee A. mellifera, and they can be safely applied to crops during flowering periods of low or no honey bee activity. It was also interesting to examine changes in the activity of AChE, carboxylesterase, PPO, and GST enzymes in insecticide-exposed surviving bees, and thus their use as biomarkers for exposure to such insecticides. Our results indicated that AChE activity rapidly decreased after exposure to these insecticides at all tested concentrations, and its specific activity depended on the dose-response curves. Therefore, the $\mathrm{IC}_{50}$ values can be useful in monitoring the environmental toxicity of these insecticides on honey bees. However, in some cases, the use of some biomarkers as an indicator of sublethal pesticide exposure is not feasible, at least not using easy-to-handle methods in the field.

Toxicité et modifications biochimiques chez les abeilles Apis mellifera exposées à quatre insecticides en conditions de laboratoire

action des insecticides / détoxification / analyse biochimique / enzyme

Toxizität und biochemische Veränderungen bei Honigbienen (Apis mellifera) nach Exposition gegenüber 4 Insektiziden unter Laborbedingungen
Insektizide Wirkung / biochemische Analyse / Entgiftung

\section{REFERENCES}

Abbott, W.S. (1925) A method of computing the effectiveness of an insecticide. J. Econ. Entomol. 18, 265-267

Abramson, C.I., Sokolowski, M.B.C., Brown, E.A., Pilard, S. (2012) The effect of pymetrozine (Plenum WG$\left.50^{\circledR}\right)$ on proboscis extension conditioning in honey bees (Apis mellifera: Hybrid var. Buckfast). Ecotoxicol. Environ. Saf. 78, 287-295

Acheampong, S., Stark, J.D. (2004) Can reduced rates of pymetrozine and natural enemies control the cabbage aphid, Brevicoryne brassicae (Homoptera: Aphididae), on brocooli? Int. J. Pest. Manage., 50, 275-279

Adams, S.M., Shepard, K.K, Greeley, M.S., Jimenez, B.D., Ryan, M.G., Shugart, L.R., McCarthy, J.F., Hinton, D.E. (1989) The use of bioindicators for assessing the effects of pollutant stress on fish. Marine Environ. Res. 28, 459-464

Aliouane, Y., el Hassani, A.K., Gary, V., Armengaud, C., Lambin, M., Gauthier, M. (2009) Subchronic exposure of honeybees to sublethal doses of pesticides: Effects on behavior. Environ. Toxicol. Chem. 28, 113-122

Atkins, E.L., Kellum, D., Atkins, K.W. (1981) Reducing pesticides hazard to honey bees: Mortality prediction techniques and integrated management strategies. Division Agric. Sci. University of California, Leaf. 2883, 22 pp. (with: Supplemental list to leaflet 2883 compiled by E. Atkins, Nov. 1990

Badiou-Bénéteau, A., Meled, M., Belzunces, L.P. (2008) Honeybee Apis mellifera acetylcholinesterase - A biomarker to detect deltamethrin exposure. Ecotoxicol. Environ. Saf. 69, 246-253

Badiou-Bénéteau, A., Carvalho, S.M., Brunet, J.L., Carvalho, G.A., Bulete, A., Giroud, B., Belzunces, L.P. (2012) Development of biomarkers of exposure to xenobiotics in the honey bee Apis mellifera: Application to the systemic insecticide thiamethoxam. Ecotoxicol. Environ. Saf. 82, 22-31

Belzunces, L., Tchamitchian, S., Brunet, J.L. (2012) Neural effects of insecticides in the honey bee. Apidologie. 43, 348-370

Blacquiere, T., Smagghe, G., Gestel, C.A.M.V., Mommaerts, V. (2012) Neonicotinoids in bees: a review on concentrations, side-effects and risk assessment. Ecotoxicology 21, 973-992

Brunet, J.L., Badiou, A., Belzunces, L.P. (2005). In vivo metabolic fate of $\left[{ }^{14} \mathrm{C}\right]$ acetamiprid in six biological compartments of the honeybee, Apis mellifera L. Pest Manage. Sci. 61, 742-748

Chanda, S.M., Mortensen, S.R., Moser, V.C., Padilla, S. (1997). Tissue-specificeffectsof chlorpyrifos on carboxylesterase and cholinesterase activity in adult rats: an in vitro and in vivo comparison. Fundam. Appl. Toxicol. 38, 148-157 
Costa, E.M., Araujo, E.L., Maia, A.V.P., Silva, F.E.L., Bezerra, C.E.S.; Silva, G.J. (2014) Toxicity of insecticides used in the Brazilian melon crop to the honey bee Apis mellifera under laboratory conditions. Apidologie 45, $34-44$

Cresswell, J.E., Desneux, N., Vanengelsdorp, D. (2012) Dietary traces of neonicotinoid pesticides as a cause of population declines in honey bees: an evaluation by Hill's epidemiological criteria. Pest Manag. Sci. 68, 819-827

Currie, R.W. (1999) Fluvalinate queen tabs for use against Varroa jacobsoni: Efficacy and impact on honey bee, Apis mellifera, queen and colony performance. Am. Bee J. 139, 871-876

Decourtye, A., Devillers, J., Cluzeau, S., Charreton, M., Pham-Delègue, M.H. (2004) Effects of imidacloprid and deltamethrin on associative learning in honeybee under semi-field and laboratory conditions. Ecotoxicol. Environ. Saf. 57, 410-419

Decourtye, A., Devillers, J., Genecque, E., Le Menach, K., Budzinski, H., Cluzeau, S., Pham-Delègue, M.H. (2005) Comparative sublethal toxicity of nine pesticides on olfactory learning performances of the honeybee Apis mellifera . Arch. Environ. Contam. Toxicol. $48,242-250$

Desneux, N., Decourtye, A., Delpuech, J.M. (2007) The sublethal effects of pesticides on beneficial arthropods. Ann. Rev. Entomol. 52, 81-106

Elbert, C., Erdelen, C., Kuehnhold, J., Nauen, R., Schmidt, H.W., Hattori, Y. (2000). Thiacloprid: a novel neonicotinoid insecticide for foliar application. Brighton Crop Protection Conference,Brighton, UK. Pests and Diseases, Vol. 2A-1,pp. 21-26.

Elbert, A., Haas, M., Springer, B., Thielert, W., Nauen, R. (2008) Applied aspects of neonicotinoid uses in crop protection. Pest Manag. Sci. 64, 1099-1105

Ellman, G.L., Courtney, D., Andres, V., Featherstone, R.M. (1961) A new and rapid colorimetric determination of acetylcholinesterase activity. Biochem. Pharm. 7, 88-95

Fattouch, S., Raboudi-Fattouch, F., Ponce, J.V.G., Forment, J.V., Lukovic, D., Marzouki, N., Vidal, D.R. (2010) Concentration dependent effects of commonly used pesticides on activation versus inhibition of the quince (Cydonia Oblonga) polyphenol oxidase. Food Chem. Toxicol. 48, 957-963

Finney, D.J. (1971) ProbitAnalysis, 3rd ed. CambridgeUniversity Press, Cambridge, pp. 318

Frasco, M.F., Fournier, D., Carvalho, F., Guilhermino, L. (2005) Do metals inhibit acetylcholinesterase (AChE)? Implementation of assay conditions for the use of AChE activity as a biomarker of metal toxicity. Biomarkers 10, 360-375

Hayes, J.D., Flanagan, J.U., Jowsey, I.R. (2005) Glutathione transferases. Ann. Rev. Pharmacol. Toxicol. 45, 51-88

Henry, M., Beguin, M., Requier, F., Rollin, O., Odoux, J.F. (2012) A common pesticide decreases foraging success and survival in honey bees. Science 336, 348-350

Hinton, B.T., Palladino, M.A., Rudolph, D., Labus, J.C. (1995) The epididymis as protector of maturing spermatozoa. Reprod. Fertil. Dev. 7, 731-745
Huang, Z.Y., Knowles, C. (1990) Nicotinic and muscarininc cholinergic receptors in honey bee (Apis mellifera) brain. Comp. Biochem. Physiol. 97, 275-281

Hyne, R.V., Maher, W.A. (2003) Invertebrate biomarkers: links to toxicosis that predict population decline. Ecotoxicol. Environ. Saf. 54, 366-374

Isayama, S., Saito, S., Kuroda, K., Umeda, K., Kasamatsu, K. (2005) Pyridalyl, a novel insecticide: potency and insecticidal selectivity. Arch. Insect Biochem. Physiol. 58, 226-33

Iwasa, T., Motoyama, N., Ambrose, J.T., Michael, R. (2004) Mechanism for the differential toxicity of neonicotinoid insecticides in the honey bee, Apis mellifera . Crop Prot. 23, 371-378

Jansen, J.P., Defrance, T., Warnier, A.M. (2011) Side effects of flonicamide and pymetrozine on five aphid natural enemy species. BioControl 56, 759-770

Johnson, R.M., Ellis, M.D., Mullin, C.A., Frazier, M. (2010) Pesticides and honey bee toxicity - USA. Apidologie 41, 312-331

Jones, A.K., Raymond-Delpech, V., Thany, S.H., Gauthier, M., Sattelle, D.B. (2006) The nicotinic acetylcholine receptor gene family of the honey bee, Apis mellifera . Genome Res. 16, 1422-1430

Lagadic, L., Cuany, A., Berge, J.B., Echaubard, M. (1993) Purification and partial characterisation of glutathione S-transferases from insecticide-resistant and lindaneinduced susceptible Spodoptera littoralis (Boisd) larvae. Insect Biochem. Mol. Biol. 23, 467-474

Laurino, D., Porporato, M., Patetta, A., Manino, A. (2011) Toxicity of neonicotinoid insecticides to honey bees laboratory tests. Bull. Insectol. 64,107-113

Lowry, O.H., Rosebrough, N.J., Farr, A.L., Randall, R.J. (1951) Protein measurement with the Folin phenol reagent. J. Biol. Chem. 193, 265-275

Mannervik, B., Lin, P., Guthenberg, C., Jensson, H., Tahir, M.K., Warholm, M., Jornvall, H. (1985) Identification of three classes of cytosolic glutathione transferases common to several mammalian species: correlation between structural data and enzymatic properties. Proc. Nat. Acad. Sci. USA 82, 7202-7206

Mayer, D.F., Lunden, J.D. (1986) Toxicity of fungicides and an acaricide to honey bees (Hymenoptera: Apidae) and their effects on bee foraging behavior and pollen viability on blooming apples and pears. Environ. Entomol. 15, 1047-1049

Mayer, D.F., Kovacs, G., Brett, B.L., Brisabri, B.L. (2001) The effects of spinosad insecticide to adults of Apis mellifera, Megachile rotundata and Nomia melanderi (Hymenoptera:Apidae). Int. J. Horticul. Sci. 7, 93-97

Medrzycki, P., Montanari, R., Bortolotti, L., Sabatini, A.G., Maini, S., Porrini, C. (2003) Effects of imidacloprid administered in sub-lethal doses on honey bee behaviour. Laboratory tests. Bull. Insectol. 56, 59-62

Mommaerts, V., Reynders, S., Boulet, J., Besard, L., Sterk, G., Smagghe, G. (2010) Risk assessment for sideeffects of neonicotinoids against bumblebees with and without impairing foraging behaviour. Ecotoxicology 19, 207-215 
Murphy, S.D. (1986) Pesticides. In: Klaassen, C.D, Amdur, M., Doull, J. (Editors), The basic science of poisons, Macmillan Publishing Co, New York.

Picard-Nizou, A.L., Pham-Delegue, M.H., Kerguelen, V., Marilleau, R., Olsen, L., Grison, R., Toppan, A., Masson, C. (1995) Foraging behavior of honey bees (Apis mellifera L.) on Transgenic Oilseed Rape (Brassica napus L. Var Oleifera). Transgenic Res. 4, 270-276

Porrini, C., Colombo, V., Celli, G. (1996) The honey bee (Apis mellifera L.) as pesticide bioindicator. Evaluation of the degree of pollution by means of environmental hazard indexes. In: Proceedings XX International Congress of Entomology, Firenze, Italy, August 25-31, 444

Porrini, C., Ghini, S., Girotti, S., Sabatini, A.G., Gattavecchia, E., Celli, G. (2002) Use of honey bees as bioindicators of environmental pollution in Italy. In: Honey Bees: Estimating the Environmental Impact of Chemicals, (Devillers J, Pham-Délègue MH (eds), Taylor \& Francis, London and New York, 186-247

Rabea, E.I., Nasr, H.M., Badawy, M.E.I. (2010) Toxic effect and biochemical study of chlorfluazuron, oxymatrine and spinosad on honey bees (Apis mellifera ). Arch. Environ. Cont. Toxicol. 58, 722-732

Rhodes, J., Scott, M. (2006) Pesticides: a guide to their effects on honey bees. NSW Department of Primary Industries: Primefacts 149

Saint-Denis, M., Labrot, F., Narbonne, J.F., Ribera, D. (1998) Glutathione, glutathione related enzymes and catalase activities in the worm Eisenia fetida. Arch. Environ. Cont. Toxicol. 35, 594-606

Schmidt, H.W. (1996) The reaction of bees under the influence of the insecticide Imidacloprid. In: Proceedings of the 6th ICP-BR International Symposium on Hazards of Pesticides, September 17-19, BBA Braunschweig, Germany,(LEWIS GB, Ed.) Appendix n. 12

Sechser, B., Reber, B., Bourgeois, F. (2002). Pymetrozine: Selectivity spectrum to beneficial arthropods and fitness for integrated pest management. Anzeiger für Schädlingskunde 75, 72-77

Singh, M., Sandhir, R., Kiran, R. (2006) Erythrocyte antioxidant enzymes in toxicological evaluation of commonly used organophosphate pesticides. Ind. Exp. Biol. 44, 580-583

Smirle, M.J., Winston, M.L., Woodward, K.L. (1984) Development of a sensitive bioassay for evaluating sublethal pesticide effects on the honey bee (Hymenoptera: Apidae). J. Econ. Entomol. 77, 63-67

Smith R.K., Wilcox M.M. (1990) Chemical residues in bees, honey and beeswax, Am. Bee J. 130, 188-192

Stone, J.C., Abramson, C.I., Price, J.M. (1997) Task dependent effects of dicofol (kelthane) on learning in the honey bee (Apis mellifera). Bull. Environ. Contam. Toxicol. 58, 177-183

Suchail, S.,Guez, D.,Belzunces, L.P. (2000) Characteristics of imidacloprid toxicity in two Apis mellifera subspecies. Environ. Toxicol. Chem. 19, 1901-1905

Suchail, S., De Sousa, G., Rahmani, R., Belzunces, L.P. (2004) In vivo distribution and metabolisation of C-14imidacloprid in different compartments of Apis mellifera L. Pest Manag. Sci. 60, 1056-1062

Thany, S.H. (2010) Neonicotinoid Insecticides. Historical evaluation and resistance mechanisms. Advances. In: Exp. Med. Biol. 683, 75-83

Tu, H.T., Silvestre, F., Scippo, M.L., Thome, J.P., Phuong, N.T., Kestemont, P. (2009) Acetylcholinesterase activity as a biomarker of exposure to antibiotics and pesticides in the black tiger shrimp (Penaeus monodon). Ecotoxicol. Environ. Saf. 72, 1463-1470

VanEngelsdorp, D., Meixner, M.D. (2010) A historical review of managed honey bee populations in Europe and the United States and the factors that may affect them. J. Invertebr. Pathol. 103, S80-S95

Velthuis, H.H.W., Van Doorn, A. (2006) A century of advances in bumblebee domestication and the economic and environmental aspects of its commercialization for pollination. Apidologie 37, 421-451

Winston, M.L. (1987). The biology of the honey bee. Harvard University Press, Cambridge.

Yamamoto, I., Casida, J.E. (1999) Nicotinoid Insecticides and the nicotinic acetylcholine receptor. Springer,Tokyo. 